\title{
Pelatihan Kewirausahaan Pembuatan Asesoris Wanita Berbahan Limbah Kain Perca
}

\author{
Nur Indah Riwajanti ${ }^{1}$, Kartika D.S. Susilowati ${ }^{2}$, Elvyra Handajani ${ }^{3}$, Muhammad Muwidha ${ }^{4}$, \\ Andi Kusuma Indrawan ${ }^{5}$ \\ 1,2,3,4,5 Jurusan Akuntansi, Politeknik Negeri Malang \\ e-mail: ${ }^{1}$ nur.indah@polinema.ac.id
}

\begin{abstract}
Abstrak
Kebutuhan sebagian anggota PKK di RW 11 Desa Merjosari Malang adalah peningkatan ketrampilan yang bisa dimanfaatkan untuk membuka usaha dan manambah pendapatan keluarga. Oleh karena itu dibuat pelatihan pembuatan asesoris wanita berbahan limbah kain perca yang banyak terdapat di lokasi tersebut. Limbah kain perca bisa dimanfaatkan untuk membuat asesoris bagi wanita sehingga memiliki nilai jual. Karena masa pandemi, pelatihan dilakukan secara online dengan mengunggah video tutorial di YouTube. Hasil evaluasi setalah pelatihan menunjukkan bahwa peserta memiliki tingkat kepuasan yang tinggi, manfaat yang besar dan kemampuan peserta untuk melanjutkan hasil pelatihan dalam memulai usaha dan mengajarkan ketrampilan ini pada warga yang lain. Peserta memberikan saran agar dapat memperoleh pelatihan lain dimasa yang akan datang.
\end{abstract}

Kata kunci-asesoris, kain perca, pendapatan keluarga

\section{PENDAHULUAN}

$\mathrm{P}$ Limbah dalam berbagai bentuk dapat dijumpai dengan mudah di lingkungan sekitar kita, baik limbah organic atau unorganik. Limbah organic dapat dicerna oleh alam sehingga tidak mengganggu lingkungan. Namun limbah un-organik tidak bisa diuraikan oleh alam sehingga akan mengganggu lingkungan. Tidak semua limbah merupakan barang tidak berguna; sebagian limbah masih bisa dimanfaatkan menjadi barang yang dapat digunakan bahkan memiliki nilai jual, misalnya limbah kain perca. Dengan memanfaatkan limbah maka kita juga berperan dalam menjaga lingkungan agar tetap nyaman sebagai tempat tinggal.

Salah satu limbah yang bermanfaat adalah limbah kain perca, yaitu potongan kain dalam ukuran kecil. Walaupun berukuran kecil, kain perca yang dihasilkan oleh usaha konfeksi maupun penjahit dalam skala kecil bisa dimanfaatkan menjadi berbagai barang, misalnya asesoris wanita dalam bentuk bros dalam berbagai desain, misalnya bunga, kupukupu dll. Cara pembuatan asesoris berbahan kain percaya ini tidak sulit dan tidak membutuhkan alat yang rumit dan mahal, sehingga hamper semua orang bisa membuat asesoris ini, termasuk para wanita ibu rumah tangga. Saat ini hampir semua perempuan menggunakan asesoris sehingga asesoris bagi wanita merupakan pelengkap penampilan, bisa dipakai di hijab, baju dsb.

Para ibu rumah tangga di PKK RW 11 Keluarahan Merjosari Kecamatan Lowokwaru sebagian tidak bekerja di luar rumah sehingga memiliki waktu luang yang bisa digunakan untuk menjalan usaha di rumah.Pemberdayaan perempuan di lingkungan rumah tangga memiliki peran penting karena akan membantu meningkatkan pendapatan keluarga. Namun masalahnya sebagian ibu tidak tahu usaha apa yang bisa dilakukan dengan modal yang sedikit dan tidak membutuhkan ketrampilan tinggi. Pelatihan memproduksi asesoris berbahan perca ini akan membuka peluang usaha bagi para ibu rumah tangga anggota PKK tersebut. Jika tidak tertarik untuk memproduksi dan menjual, maka asesoris bisa dipakai sendiri atau sebagai hadiah bagi keluarga.

Para mitra yang merupakan ibu-ibu PKK ini membutuhkan informasi dan 
pelatihan teknis yang bisa digunakan untuk bekal usaha. Usaha yang diminati para ibu ini memiliki kriteria tidak membutuhkan modal besar, alat yang mahal dan ketrampilan yang sangat tinggi, bisa dikerjakan di rumah saat waktu luang. Dengan usaha sampingan ini, para ibu berhadap bisa menambah penghasilan tanpa harus meninggalkan rumah dan keluarga. Kegiatan ini bertujuan untuk memberikan motivasi dan tambahan ketrampilan dalam memproduksi asesoris berbahan kain perca melalui pelatihan teknis.

\section{KAJIAN PUSTAKA}

\subsection{Peluang Usaha Asesoris Wanita}

Wanita modern pada umunya ingin tampil dengan anggun, menawan dan modis dalam berbagai acara. Berbagai cara dilakukan wanita agar nampak menarik disetiap penampilan, salah satunya dengan mengenakan asesoris yang sesuai. Maka tak heran jika banyak wanita yang senang hanya membeli aksesoris untuk wanita saja. Hal ini membuat prospek pasar aksesoris wanita menjadi sangat menarik.

Kreatifitas dalam mengolah produk yang mengikuti trend adalah kunci sukses menjalankan usaha asesoris wanita. Wanita juga memiliki keunggulan yaitu ketekunan dan kesabaran dalam membuat produk yang membutuhkan ketrampilan khusus yang dibuat secara handmade. Oleh karena itu, membuka usaha aksesoris wanita memberi peluang usaha yang sangat menjanjikan. Untuk memulai, disarankan untuk membuat produk yang mudah dibuat dan tidak membutuhkan biaya yang tinggi. Potensi dan prospek keuntungan usaha asesoris juga sangat menjanjikan jika mampu memproduksi asesoris yang diminati masyarakat.

Membuka usaha aksesoris wanita dapat dijalankan dengan mudah relative tidak rumit dibandingkan dengan usaha yang lain. Bisa dikatakan siapa saja bisa menjalankan sudaha ini asalkan memiliki niat, tekun dan mau bekerja meluangkan waktu. Usaha bisa diawali dengan membeli produk secara grosir kemudian menjual kembali pada masyarakat, baik secara online maupun offline. Namun akan lebih baik bila pengusaha pemula juga memiliki desain sendiri sendiri memiliki keunikan jika dibandingkan dengan produk yang lain. Keunikan ini akan menjadi nilai jual, apalagi jika produk dibuat terbatas dan berbeda untuk setiap produknya sehingga bersifat eksklusif. Sebagian wanita sangat menginginkan produk yang eksklusif walaupun dijual dengan harga mahal.

Prospek usaha asesoris wanita sangat bagus Hal ini disebabkan oleh kepedulian wanita untuk selalu mengikuti trend fashion. Sudah cukup banyak contoh pengusaha wanita yang sukses membangun bisnis dibidang asesoris wanita. Untuk memulai usaha ini tidak terlalu sulit dan bisa dimulai dengan modal yang minimal dengan menggunakan bahan- bahan yang murah dan tersedia dilingkungan sekitar, misalnya kain perca dari penjahit yang biasanya dibuang tanpa dimanfaatkan (Purwanthari, Obed, Wildani, Firmansyah, \& Purnamasari, 2017).. Dengan memanfaatkan limbah yang terbuang, ternyata bisa menambah penghasilan masyarakat (Suliyanthini et al., 2019). Selain itu, ketrampilan ini bisa meningkatkan kualitas sumber daya manusia khususnya peningkatan skills berkarya (Anindita, Setiawan, Asri, \& Sari, 2017; Devanti, 2017).

\subsection{Jenis asesoris wanita}

Terdapat berbagai jenis asesoris wanita, namun bisa digolongkan dalam kelompok sebagai berikut: perhiasan, tas, sepatu, ikat pinggang, jam tangan, pakaian luar (outwear), syal atau pashmina. Khusus untuk muslimah, aksesoris juga termasuk kain hijab dengan berbagai bentuk yang digunakan dengan berbagai macam bros dari berbagai jenis bahan. Bros bisa dibuat dari bahan batu hias, mutiara, plastic, clay, bahkan logam mulai emas dan perak. Bros juga bisa dibuat dengan mamanfaatkan bahan-bahan yang selama ini dibuang misalnya kain perca, plastic bungkus kemasan produk sabun dll. Kreatifikas adalah kunci agar produk yang dihasilkan memiliki nilai jual tinggi.

\subsection{Aspek Pemasaran}

Bagi pengusaha pemula, disarankan untuk tidak menetapkan harga jual yang terlalu tinggi. Pada titik awal ini, focus utamanya adalah mengenalkan produk pada masyarakat. Harga ditetapkan untuk setiap item produk dengan keuntingan berkisar antara Rp 500 
samai Rp 10.000 tergantung pada jenis produk.

Tingkat penjualan produk sangat dipengaruhi oleh strategi promosi dan pemasaran. Usaha aksesoris wanita dapat dilaksanakan dengan menggunakan pemasaran yang sederhana menggunakan media social dan koneksi keluarga, teman, saudara, kenalan. Media social saat ini sudah sangat powerful untuk pemasaran, misalnya: Facebook, Instagram, WhatsApps, dll. Penting untuk selalu update informasi di

media social dan mencantumkan pendapat/testimoni dari konsumen yang puas dengan produk yang sudah dibelinya.

Konsumen asesoris adalah hampir semua wanita karena semua wanita peduli dengan penampilan yang menarik. Namun perlu diperhatikan bahwa jenis aksesoris yang dijual sesuai dengan perkembangan trend mode. Trend mode sering berubah, sehingga harus jeli dan update dengan perkembangan yang ada.

Perlu diperhatikan bahwa tingkat persaingan sangat ketat karena banyaknya pelaku bisnis yang sama. Karena usaha ini mudah dijalankan, banyak wanita membuka usaha serupa. Kunci sukses bersaing adalah inovasi produk, keunikan yang tidak dimiliki oleh produk lain, harga yang terjangkau dan pemasaran secara online melalui media sosial.

\section{SOLUSI DAN METODE PELAKSANAAN}

\subsection{Solusi}

Berdasarkan masalah yang dijelaskan pada bagian sebelumnya, kegiatan pelatihan dalam PkM ini dijalankan untuk memberikan solusi bagi ibu-ibu PKK RW 11 Kelurahan Merjosari dalam meningkatkan ketrampilan yang bisa digunakan untuk membuka usaha baru dibidang produksi asesoris berbahan lain perca. Manfaat yang diperoleh dari penelitian ini adalah:

1. Ibu-ibu PKK RW 11 Kelurahan Merjosari memperoleh tambahan ketrampilan untuk membuat produk asesoris berbahan kain perca yang mudah dibuat.

2. Ibu-ibu memperoleh peluang untuk mengembangkan usaha memproduksi asesoris berbahan kain perca yang bisa menambah pendapatan keluarga.

3. Meningkatkan motivasi para ibu anggota PKK RW 11 untuk memulai usaha dari rumah.

Meningkatkan hubungan kerjasama antara Politeknik Negeri Malang dan masyarakat lingkungan sekitar kampus, dalam hal ini RW 11 Kelurahan Merjosari Malang.

\subsection{Metode Pelaksanaan}

Dalam melakukan kegiatan

Pengabdian pada Masyarakat, berikut ini adalah urutan metode yang dilakukan:

1. Survey lapangan untuk mengamati situasi di RW 11 Kelurahan Merjosari.

2. Melakukan koordinasi dengan warga masyarakat khususnya PKK dan ibu RW.

3. Sosialisasi program pengabdian masyarakat pada ibu RW 11 Kelurahan Merjosari.

4. Memberikan paket lengkap peralatan dan bahan untuk membuat asesoris bros kain perca kepada 21 orang peserta pelatihan.

5. Ibu RW 11 Kelurahan Merjosari membuat grup WhatsApp untuk semua peserta pelatihan.

6. Pelatihan tentang pembuatan asesoris berbahan kain perca secara online melalui video yang dipublikasikan di YouTube sehingga peserta pelatihan bisa mengulang beberapa kali jika ada yang kurang dipahami.

7. Peserta pelatihan praktek membuat asesoris kain perca.

8. Foto hasil karya peserta pelatihan di upload di grup WhatsApp.

9. Beberapa peserta pelatihan secara mandiri saling belajar membuat asesoris kain perca secara offline dengan peserta lain yang memiliki hasil karya yang terbaik di grup.

10. Peserta pelatihan mengisi Kuesioner Kepuasan Mitra Pengabdian Masyarakat secara online dengan google forms yang disebarkan melalui grup WhatsApp.

Dengan mempertimbangkan kondisi pandemi yang tidak memungkinkan untuk mengumpulkan masyarakat dalam jumlah banyak, maka dipilih metode online dengan 
menggunakan video tutorial tentang membuat asesoris dari kain. Video ini diunggah di YouTube (link https://www.youtube.com/watch?v=N7sLQ54Il w0\&app=deskt op).

\section{HASIL DAN PELAKSANAAN PKM}

\subsection{Pelaksanaan Kegiatan}

Kegiatan diawali dengan melakukan survey lapangan untuk mengamati situasi di RW 11 Kelurahan Merjosari. Dari survey ini diperoleh informasi bahwa ibu-ibu PKK membutuhkan pelatihan yang bersifat praktis untuk bisa diaplikasikan dalam usaha yang mudah dikerjakan, tidak membutuhkan modal besar dan bisa dikerjakan dari rumah karena para ibu rumah tangga ini memiliki kewajiban untuk mengerjakan pekerjaan rumah tangga dan mendampingi putra putri mereka selama masa belajar di rumah karena Pandemi.

Selanjutnya, dilakukan koordinasi dengan warga masyarakat khususnya PKK dan ibu RW 11 Kelurahan Merjosari. Selain itu, dilakukan juga sosialisasi program pengabdian masyarakat pada ibu RW 11 Kelurahan Merjosari. Setelah niat ini disambut baik oleh ibu RW dan masyarakat setempat, maka paket lengkap peralatan dan bahan untuk membuat asesoris bros kain perca kepada 21 orang peserta pelatihan. Paket diserahkan kepada para peserta melalui ibu RW 11 Kelurahan Merjosari. Para peserta yang dipilih oleh ibu RW terdiri dari perwakilan dari masingmasing 17 RT yang ada di RW 11.

Setelah menerima 21 paket tersebut, Ibu RW 11 Kelurahan Merjosari mengumumkan kepada para peserta untuk mengambil paket tersebut di rumah ibu RW 11. Untuk kemudahan komunikasi antara pemateri PkM dan seluruh peserta, maka Ibu RW membuat grup WhatsApp untuk semua peserta pelatihan. Karena masa pandemi yang tidak memperbolehkan adanya masyarakat yang berkumpul, maka pelatihan tentang pembuatan asesoris berbahan kain percadilakukan secara online melalui video yang dipublikasikan di YouTube. Video pelatihan diunggah dengan alamat web: https://www.youtube.com/watch? $\mathrm{v}=\mathrm{N}$ 7sLQ54Ilw0\&app $=$ deskt op.

Sejak diunggah tanggal 1 Agustus 2020 hingga tanggal 12 September 2020, video ini sudah disaksikan sebanyak 103 kali. Kelebihan menggunakan video ini adalah para peserta pelatihan bisa mengulang beberapa kali jika ada yang kurang

dipahami. Selain itu, mereka memiliki kebebasan untuk memilih waktu luang yang tepat untuk praktek membuat asesoris ini. Para peserta memiliki waktu selama satu minggu sejak menerima paket untuk menonton video dan praktek membuat asesoris.

Bahan yang dibutuhkan untuk membuat kain perca ini sangat sederhana, yaitu kain perca, alas bros, peniti bros dan lem tembak. Alat yang dipakai juga sederhana, yaitu gunting, pinset, lilin dan lem tembak. Semua alat dan bahan sudah diberikan pada peserta. Proses pembuatan kain perca diawali dengan memotong kain dengan ukuran diameter $3,5 \mathrm{~cm}$ sesuai pola sebanyak 18 potong yang akan digunakan sebagai kuntum bunga tiga tingkat. Selanjutnya, tepi kain dibakar menggunakan lilin agar melengkung seperti kuntum bunga. dengan uang logam. Agar lekukan kain terbentuk dengan bagus, digunakan uang logam $\mathrm{Rp} 100$ sebagai cetakan. Saat membakar, digunakan pinset untuk memegang kain. Langkah berikutnya adalah menggabungkan kuntum-kuntum bunga sebanyak tiga tingkat, masing-masing: 7 kuntum tingkat pertama, 5 kuntum tingkat kedua, dan 3 kuntum tingkat ketiga. Untuk menggabungkan kuntum digunakan lem tembak. Selanjutnya tiga kuntum tersebut ditumpuk sehingga membentuk bunga yang cantik. Bunga yang sudah terbentuk akan diberi alas bros dan peniti dengan menggunakan lem tembak agar bisa digunakan di jilbab/baju dan bisa mempercantik penampilan wanita.

\subsection{Evaluasi Hasil Kegiatan}

Setelah selesai mengikuti pelatihan, para peserta diminta untuk mengisi kuesioner kepuasan mitra menggunakan google forms melalui link https://forms.gle/sbnDoSJmtK41YmLd8. Link ini disebarkan secara online melalaui grup WhatsApps.

Sebanyak 13 peserta memberikan respon dengan mengisi kuesioner. Berdasarkan hasil kuesioner, kepuasan terbesar peserta terdapat pada aspek alat/perlengakapan yang disediakan. Tidak ada satupun peserta yang 
menjawab tidak puas pada semua aspek. Hasil kepuasan para mitra ditampilkan dalam tabel berikut:

Tabel 1. Kepuasan peserta pelatihan dari berbagai aspek

\begin{tabular}{|l|c|c|c|c|c|}
\hline \multicolumn{1}{|c|}{ Pertanyaan } & $\begin{array}{c}\text { Sangat } \\
\text { puas }\end{array}$ & Puas & $\begin{array}{c}\text { Cukup } \\
\text { puas }\end{array}$ & $\begin{array}{c}\text { Tidak } \\
\text { puas }\end{array}$ & Total \\
\hline $\begin{array}{l}\text { Bagaimana kepuasan ibu } \\
\text { keghadap } \\
\text { pengabdian dari aspek: }\end{array}$ & 2 & 9 & 2 & 0 & 13 \\
\hline $\begin{array}{l}\text { Metode atau cara } \\
\text { penyampaian materi }\end{array}$ & 3 & 8 & 0 & 0 & 11 \\
\hline $\begin{array}{l}\text { Materi yang diberikan } \\
\text { (bros kain) }\end{array}$ & 3 & 8 & 1 & 0 & 12 \\
\hline $\begin{array}{l}\text { Pelaksanaan kegiatan } \\
\text { PkM }\end{array}$ & 7 & 3 & 1 & 0 & 11 \\
\hline Alat/perlengkapan & & & & & \\
\hline
\end{tabular}

Terkait manfaat pelatihan, 8 orang peserta menjawab bahwa pelatihan sangat bermanfaat dan 4 orang peserta menyatakan manfaat, sebagaimana ditunjukkan dalam tabel dan grafik berikut:

Tabel 2. Kemanfaatan Kegiatan

\begin{tabular}{|l|c|c|c|c|c|}
\hline \multicolumn{1}{|c|}{ Pertanyaan } & $\begin{array}{c}\text { Sangat } \\
\text { manfaat }\end{array}$ & $\begin{array}{c}\text { Man } \\
\text { faat }\end{array}$ & $\begin{array}{c}\text { Cukup } \\
\text { Manfaat }\end{array}$ & $\begin{array}{c}\text { Tidak } \\
\text { Manfaat }\end{array}$ & Total \\
\hline $\begin{array}{l}\text { Bagaimana pendapat ibu } \\
\text { mengenai kemanfaatan } \\
\text { kegiatan pengabdian }\end{array}$ & 8 & 4 & 1 & 0 & 13 \\
$\begin{array}{l}\text { yang } \\
\text { telah dilaksanakan? }\end{array}$ & & & & & \\
\hline
\end{tabular}

Terkait manfaat pelatihan, 8 orang peserta menjawab bahwa pelatihan sangat bermanfaat dan 4 orang peserta menyatakan manfaat, sebagaimana ditunjukkan dalam tabel dan grafik berikut:

\begin{tabular}{|l|c|c|c|c|c|}
\hline \multicolumn{1}{|c|}{ Pertanyaan } & $\begin{array}{c}\text { Sangat } \\
\text { manfaat }\end{array}$ & manfaat & $\begin{array}{c}\text { Cukup } \\
\text { manfaat }\end{array}$ & $\begin{array}{c}\text { Tidak } \\
\text { manfaat }\end{array}$ & Total \\
\hline $\begin{array}{l}\text { Bagaimana } \\
\text { pendapat ibu } \\
\text { mengenai } \\
\text { kemanfaatan }\end{array}$ & 8 & 4 & 1 & 0 & 13 \\
$\begin{array}{l}\text { kegiatan } \\
\text { pengabdian } \\
\text { yang telah } \\
\text { dilaksanakan? }\end{array}$ & & & & & \\
\hline
\end{tabular}

Untuk menggali jawaban lebih detail tentang bagaimana peserta melanjutkan dan memanfaatkan materi dalam pelatihan, maka pertanyaan ini dimasukkan dalam kuesioner. Terdapat beragam jawaban dari para peserta, namun tema utama jawaban adalah ketrampilan tersebut akan digunakan untuk membuka usaha kecil dan akan mengajarkan pada ibu-bu yang lain. Hal ini menunjukkan bahwa pelatihan sudah mencapai sasaran yang diharapkan yaitu peningkatan ketrampilan yang bisa digunakan untuk membuka usaha. Para peserta memberikan saran-saran yang sangat baik. Mereka menyarankan untuk memberikan pelatihan lagi dengan materi/ketrampilan yang lebih bervariasi/berbeda dan tidak hanya sekali saja.

\section{SIMPULAN DAN SARAN}

\subsection{Simpulan}

Dari hasil kegiatan pelatihan yang sudah dilaksanakan di PKK RW 11 Kelurahan Merjosari, bisa diambil simpulan bahwa ibuibu PKK memiliki minat untuk terus mengembangkan kemampuan dan ketrampilan berkarya. Mereka mengharapkan agar ketrampilan itu bisa dimanfaatkan untuk membangun usaha yang mudah, murah dan bisa dikerjakan di rumah untuk meningkatkan ekonomi keluarga.

Walaupun kondisi pandemi tidak memungkinkan untuk melaksanakan pelatihan secra langsung (offline), namun tidak menghalangi untuk tetap melakukan kegiatan secara

online dengan mengunggah video di YouTube. Dengan dukungan ibu RW dan para peserta pelatihan, pelaksanaan pelatihan bisa berjalan dengan lancar. Bahkan pelatihan online ini memberikan fleksibilitas waktu pada para peserta untuk menentukan sendiri waktu yang luang untuk praktek membuat asesoris setelah melihat video tutorial.

Respon dari para peserta sangat menggembirakan, hal ini bisa dilihat dari hasil survey online yang dilakukan setelah pelatihan. Hampir seluruh peserta menyatakan sangat puas dan puas, tidak ada satupun yang menyatakan tidak puas. Dari sisi kemanfaatan, hampir seluruh peserta menyatakan bahwa pelatihan sangat bermanfaat dan bermnfaat, tidak ada yang menyatakan tidak bermanfaat. Selain itu, seluruh peserta menyatakan bahwa ketrampilan yang diperoleh dari pelatihan bisa dilanjutkan dalam bentuk usaha menjual asesoris kain perca atau mengajarkan ketrampilan tersebut pada warga lain. Peserta juga memberikan saran agar mereka bisa 
memperoleh kesempatan untuk mendapatkan pelatihan lain.

\subsection{Saran}

Saran yang diberikan pada institusi adalah dosen bisa memberikan pelatihan ketrampilan pembuatan produk yang bersifat teknis dan bisa digunakan untuk membuka usaha baru dengan biaya murah dan cara yang mudah. Selain itu, dosen bisa melakukan pelatihan untuk mengelola keuangan usaha kecil sehingga para pemilik usaha mikro kecil.

\section{DAFTAR PUSTAKA}

Anindita, G., Setiawan, E., Asri, P., \& Sari, D. P. (2017). Pemanfaatan Limbah Plastik dan Kain Percaya Menjadi Kerajinan Guna Meningkatkan Kualitas Sumber Daya Manusia. Seminar MASTER.

Devanti, Y. M. (2017). Pemanfaatan Limbah Konveksi untuk Meningkatkan Pendapatan Rumah Tangga Miskin (RTM). Jurnal Pengabdian Masyarakat Ipteks, Vol. 3(No. 1 Juni), 51-56.

Purwanthari, A., Obed, A., Wildani, A., Firmansyah, A., \& Purnamasari, D. (2017). Pelatihan Pembuatan Bross dengan Bahan Kain Perca Desa Cangkringturi Kecamatan Prambon Kabupaten Sidoarjo. Abdimas Adi Buana, Vol. 1(No. 1).

Suliyanthini, D., Choliwati, Utari, D., Amanda, R., Saraswati, L., Nabilah, B., \& Lestari, R. D. (2019). Tingkat Kepuasan Peserta Pengabdian Masyarakat dan Kuliah Kerja Nyata Kegiatan Pelatihan Membuat Aksesori Pelengkap Busana Jurnal Pengabdian Masyarakat, 16(2), 138-146. 